\title{
STORYTELLING VARIATIONS AND STUDENT WRITING ABILITY IN MADRASAH IBTIDAIYAH
}

\author{
A. Jauhar Fuad \\ Institut Agama Islam Tribakti Kediri \\ E-mail: info.ajauharfuad@gmail.com \\ Dwi Agus Tintati Sari \\ E-mail:dwiagusts@gmail.com \\ Institut Agama Islam Tribakti Kediri
}

\begin{abstract}
This paper is to find out learning that uses fairy tale methods and increase students' literacy skills in rewriting the contents of fairy tales. Researchers use classroom action research. Data collection techniques with observation and writing ability tests, with skinative and quantitative analysis techniques. Research findings: there is an increase in the ability to rewrite fairy tales read from cycle I to cycle II. There are variations in storytelling techniques by utilizing various learning media in the form of images, audio visuals and the surrounding environment.
\end{abstract}

Keywords: Fairy Tale Method, Literacy Ability, Rewriting Ability

\section{INTRODUCTION}

Literacy is an important activity in life. The educational process depends on literacy skills. Students are asked to have the ability to read, such as understanding the text analytically, critically, and reflective (Wiedarti et al. 2016, 1). In order to fulfill that expectation, the government made a School Literacy Movement (GLS) program as an effort to improve student literacy skills (Widayoko, Koes, and Muhardjito 2018, 78). This program is basically an activity that focuses on students' reading and writing skills by involving all school members and the community, as part of the education ecosystem (Faizah et al. 2016, ii), or social movements with collaborative support from various elements (Wiedarti et al. 2016, 7). 
The progress of a nation's civilization is also determined by how many people read. Not unlike reading, writing also has its own role for someone's life. Writing skills are more complex than kinesthetic activities and higher levels of cognitive activity that must be considered along with reading skills (Çakıroğlu 2012, 702). Writing activities have a more difficult level than reading, because when someone is able to write, someone indirectly has reading skills.

The ability to write is not an ability that can be obtained by itself, but a long learning process to have this ability. This is what encourages someone from birth in the world to learn to read and write from parents and the surrounding environment (Burgess, Hecht, and Lonigan 2002, 412). Writing is one of the skills that can show the quality of student literacy skills (Rini, Harsiati, and Basuki 2017, 498).

The interest in reading and writing is created not only when someone has entered the world of education (Khairuddin 2013, 16), but when he is in a family environment or social environment, that interest can be created (Squires 2014). Literacy activities are related to students' interest in reading (Faradina 2017, 60).

At this time literacy activities have been seen as a necessity that must be done by every student in elementary school (Wiedarti et al. 2016; Faizah et al. 2016). One literacy activity can be carried out by storytelling. This activity can trigger the power of super thinking, which releases students' imagination (Patimah 2015, 1). Through this stage, it is expected that interest in reading and writing can be cultivated (Shofaussamawati 2016, 15).

The results of the study show that storytelling is well used in learning, because students are more interested in the existence of fairy tales in learning. Storytelling is expected to improve students' thinking and improve intelligence. The teacher can enter all forms of messages that will be remembered by students, because in telling stories there is no impression of degrading or commanding so students are more comfortable and happy (Agustini 2015, 26). Storytelling can attract students' attention in learning. Storytelling can facilitate students in understanding values (Hidayah and Nurhadija 2018, 73).

By mastering good storytelling techniques, the teacher has the opportunity to explore the intelligence potential of students, intelligence, 
social, and spiritual intelligence. Through fairy tales, teachers can also arouse students' curiosity through various types of stories, such as stories about animals or fairy tales and about humanity and surrounding objects. Through fairy tales, it can also lure students to always remember the various values and knowledge that are inserted in a story. The results of the study show listening to tales influences students' language skills (Azkiya and Iswinarti 2016, 123). This paper is to find out how to tell and students' literacy skills in rewriting the stories conveyed by the teacher.

\section{VARIANTS AND FUNCTIONS OF STORYTELLING}

Fairy tales are stories about something that doesn't make sense, doesn't happen correctly, and is fantastic or imaginary (Yuwono 2007, 27). Fables are fictional stories, fictional stories that are considered not really happening, there are several aspects in it, namely: intellectual aspects, aspects of sensitivity, subtlety, emotion, art, fantasy, and imagination, not only prioritizing the left brain, but also the right brain (Asfandiyar 2009, 19).

Storytelling is one of the oldest folk arts that invites students on interesting trips and at the same time teaches them about history, culture, and moral values. Fairy tales can be used effectively as a starting point for discussing personal issues and social values ((Ahyani 2010, 19). It can be concluded that mendongen is a series of ways used by the teacher to deliver material to students by telling events that did not really occur, which contained messages. This message is conveyed through unique words and facial expressions.

In storytelling there are several variations that can be used by the teacher. Among them are; reading directly from story books, storytelling using illustrated images from books, storytelling using flannel boards, storytelling using puppet media, telling stories using or playing fingers (Mukhtar et al. 2013, 111).

People think that fairy tales are a bedtime story, because the story provides some moral journey. Fairy tales have the following functions: (1) As a system of projection of desires hidden from certain people or groups of people, (2) as a means of notifying social institutions and cultural institutions, (3) as a means of pedagogy, the contents of the story contain teachings, philosophical morality, and religion, (4) As an ill-hearted entertainer, (5) As a channel for 
existing tension in society, and (6) As a control of society or a social process. The contents of the story contain fraud in the community (Danandjaja 2002, 41-42).

\section{LITERACY ABILITY}

Literacy at the beginning of its appearance is interpreted as literacy or literacy which focuses primarily on the ability to read and write, two skills that are the basis for literacy in various ways. In subsequent developments, literacy is interpreted as literacy, writing, and numbers, three basic skills for life skills (Sultan et al. 2017, 159).

Traditionally, literacy is seen as the ability to read and write. People who can be said literate in this view are people who are able to read and write or are illiterate. Understanding literacy further develops into the ability to read, write, speak, and listen. Over time, the definition of literacy has shifted from a narrow understanding to a broader understanding that covers a variety of other important fields. This change is caused by various factors, both the expansion of meaning due to wider users, the development of technology and information technology, and changes in analogies. If discussed comprehensively, changes to the concept of literacy have occurred in at least five generations (Abidin, Mulyati, and Yunansah 2017, 1).

Literacy can be defined as the ability to read and write. Furthermore, this ability is also related to the habit of reading and appreciating literature and evaluating it. However, broader literacy is related to life-long thinking and learning to survive in social and cultural environments (Kern 2000,3).

Literacy literacy is not a simple process but a complex process. This is because reading is a thinking and reasoning activity that involves activities: recognizing, interpreting, judging, reasoning, even solving various problems so that the involvement of reasoning power becomes very dominant (Sultan et al. 2017, 160). Writing skills are language skills that are used to communicate indirectly, not face to face with others (Tarigan 2013,3). In the concept of literacy, writing is an iterative process by the author to revise his ideas, repeat the writing stage, to be able to devote these ideas and ideas in written form that fits the ideas or ideas he develops (Abidin, Mulyati, and Yunansah 2017, 207). Writing is lowering or describing graphic symbols that describe a language that is understood by someone so that other people can read graphic 
symbols if they understand language and graphical descriptions (Tarigan 2013, 22).

\section{THE RELATIONSHIP BETWEEN STORYTELLING AND LITERACY}

Literacy activities are one of the important activities in life. Some educational processes depend on literacy skills and awareness. Literacy culture that is embedded in the younger generation influences the level of success both at the education level and in social life (Suragangga 2017, 154). So, literacy culture is very much needed in life especially must be planted starting from basic education such as in Madarasah Ibtidaiyah.

Teachers who teach in elementary schools such as MI are required to direct their students to be aware of the culture of literacy. There are various kinds of ways for teachers to introduce or teach literacy culture to students, one of them is by using a fairy tale method. Storytelling also has the function of entertainment, educating emotions, imagination, and creativity, and improving language skills, and student vocabulary. Teachers with storytelling in the learning process generally must have students with good literacy skills compared to teachers who only teach conventionally in the classroom. Habits arising from storytelling activities can provide many positive effects on students' literacy skills both in their ability to read, write and speak (Patimah 2015, 17).

\section{RESEARCH METHODS}

The form of this research is classroom action research which is a reflective action by actors to improve the learning process. Classroom Action Research is a reflection of learning activities in the form of an action, which is deliberately raised and occurs in the classroom simultaneously. The action is given by the teacher or by the teacher's direction made by the student. PTK can be said to be successful if students have learned a lot not how many teachers act (Fuad 2012, 3; Fuad and Winarsih 2018).

This research was conducted at MI Sunan Ampel which is located at Jl. K.H. Baedowi, Wonorejo, Semanding, Pagu, Kediri. The time of this study is in the second semester of the school year 2017/2018. As the subjects in this study were class II MI Sunan Ampel with a total of 38 students, namely 17 female students and 21 male students. 
The technique of collecting data uses observation and tests. Observation is carried out during the learning process. Test the ability to rewrite the contents of a fairy tale. Researchers develop rubric assessment of students' essays.

Table 1. Writing Ability Assessment Rubric

\begin{tabular}{|c|c|c|c|c|}
\hline \multirow{2}{*}{ Criteria } & Very good & Well & Enough & Less \\
\hline & (4) & (3) & $(2)$ & (1) \\
\hline $\begin{array}{l}\text { The idea } \\
\text { presented }\end{array}$ & $\begin{array}{l}\text { Story ideas } \\
\text { provide a sharp } \\
\text { picture, } \\
\text { showing unity } \\
\text { of all forms, } \\
\text { flowing flow, } \\
\text { detailed } \\
\text { background, } \\
\text { life story. }\end{array}$ & $\begin{array}{l}\text { Story ideas give } \\
\text { a picture of } \\
\text { something sharp, } \\
\text { showing the } \\
\text { unity of the } \\
\text { whole form, } \\
\text { flowing flow, } \\
\text { detailed } \\
\text { background, but } \\
\text { the story is less } \\
\text { alive. }\end{array}$ & $\begin{array}{l}\text { The story idea } \\
\text { gives a picture of } \\
\text { something quite } \\
\text { sharp, showing } \\
\text { the unity of the } \\
\text { whole form, the } \\
\text { flow less flowing, } \\
\text { the background is } \\
\text { not detailed, the } \\
\text { story is less alive. }\end{array}$ & $\begin{array}{l}\text { Story ideas give } \\
\text { a picture of a } \\
\text { thing, but it is } \\
\text { not sharp, does } \\
\text { not show a } \\
\text { unified form that } \\
\text { is intact, the plot } \\
\text { does not flow, } \\
\text { the background } \\
\text { is not detailed, } \\
\text { the story does } \\
\text { not live. }\end{array}$ \\
\hline $\begin{array}{l}\text { Content } \\
\text { organizati } \\
\text { on }\end{array}$ & $\begin{array}{l}\text { Writing a short } \\
\text { story } \\
\text { containing a } \\
\text { complete flow } \\
\text { framework, } \\
\text { namely the } \\
\text { stage of } \\
\text { introduction, } \\
\text { emergence of } \\
\text { conflict, climax, } \\
\text { and the final } \\
\text { stage of the } \\
\text { story, has good } \\
\text { cohesion and } \\
\text { coherence. }\end{array}$ & $\begin{array}{l}\text { Writing short } \\
\text { stories } \\
\text { containing } \\
\text { incomplete flow } \\
\text { frameworks, } \\
\text { there are only } \\
\text { stages of } \\
\text { recognition and } \\
\text { conflict, climax, } \\
\text { but still have } \\
\text { good cohesion } \\
\text { and coherence. }\end{array}$ & $\begin{array}{l}\text { Writing short } \\
\text { stories } \\
\text { immediately leads } \\
\text { to conflict, but still } \\
\text { shows good } \\
\text { cohesion and } \\
\text { coherence. }\end{array}$ & $\begin{array}{l}\text { Writing short } \\
\text { stories } \\
\text { immediately } \\
\text { causes conflict } \\
\text { and does not } \\
\text { have good } \\
\text { cohesion and } \\
\text { coherence. }\end{array}$ \\
\hline $\begin{array}{l}\text { Language } \\
\text { style, } \\
\text { structure } \\
\text { and } \\
\text { vocabular } \\
\text { y }\end{array}$ & $\begin{array}{l}\text { Sentences that } \\
\text { are used } \\
\text { effectively and } \\
\text { communicative } \\
\text { ly, right and } \\
\text { varied, } \\
\text { meaning } \\
\text { unambiguous, }\end{array}$ & $\begin{array}{l}\text { There are } \\
\text { sentences that } \\
\text { are ineffective } \\
\text { and ambiguous, } \\
\text { there is } \\
\text { something } \\
\text { wrong in the } \\
\text { context, the use }\end{array}$ & $\begin{array}{l}\text { The sentence used } \\
\text { is ineffective and } \\
\text { ambiguous, } \\
\text { because many } \\
\text { contexts are } \\
\text { wrong, the use of } \\
\text { many } \\
\text { conjunctions is }\end{array}$ & $\begin{array}{l}\text { Need help in } \\
\text { using language } \\
\text { style, structure } \\
\text { and vocabulary. }\end{array}$ \\
\hline
\end{tabular}

MODELING, Volume 6, Nomor 1, Maret 2019 | 18 


\begin{tabular}{|c|c|c|c|c|}
\hline & $\begin{array}{l}\text { the application } \\
\text { of conjunctions } \\
\text { appropriately. }\end{array}$ & $\begin{array}{l}\text { of conjunctions } \\
\text { is wrong. }\end{array}$ & wrong. & \\
\hline $\begin{array}{l}\text { Use of } \\
\text { spelling / } \\
\text { punctuati } \\
\text { on }\end{array}$ & $\begin{array}{l}\text { Able to use } \\
\text { spelling / } \\
\text { punctuation } \\
\text { properly and } \\
\text { correctly. }\end{array}$ & $\begin{array}{l}\text { There are 1-3 } \\
\text { spelling / } \\
\text { punctuation } \\
\text { usage errors in } \\
\text { writing. }\end{array}$ & $\begin{array}{l}\text { There are more } \\
\text { than } 3 \text { spelling / } \\
\text { punctuation } \\
\text { errors in writing. }\end{array}$ & $\begin{array}{l}\text { Need help in } \\
\text { using spelling / } \\
\text { punctuation } \\
\text { properly and } \\
\text { correctly. }\end{array}$ \\
\hline $\begin{array}{l}\text { Writing } \\
\text { capital } \\
\text { letters }\end{array}$ & $\begin{array}{l}\text { Able to use } \\
\text { capital letters } \\
\text { correctly and } \\
\text { correctly. }\end{array}$ & $\begin{array}{l}\text { There are } 1-3 \\
\text { errors in using } \\
\text { capital letters. }\end{array}$ & $\begin{array}{l}\text { There are more } \\
\text { than } 3 \text { errors in } \\
\text { using capital } \\
\text { letters. }\end{array}$ & $\begin{array}{l}\text { Need help in } \\
\text { using capital } \\
\text { letters. }\end{array}$ \\
\hline
\end{tabular}

Data analysis techniques use skinative analysis and quantitative analysis. Qualitative data analysis is done to describe the results of field observations and student task documentation. Qualitative data is presented in sentences separated by categories to obtain conclusions. Quantitative data presentations are presented in percentages and numbers. The percentage is adjusted by considering the student learning completeness criteria which are grouped into two categories, namely complete and incomplete. Minimum completeness criteria for subject 75 .

\section{LEARNING PROCESS WITH MENDONGEN IN CYCLE I Cycle I Action Plan}

Cycle I action research discusses rewriting tales. Basic Competence (KD) explores information from animal fables (fables) about harmonious living attitudes from oral and written texts. While the indicators to be achieved are: (a) understanding and finding the contents of fairy tales with honesty and confidence, (b) linking the content of fairy tales with everyday life, (c) Finding, imitating, correcting, and writing greetings in fairy tales correctly, (d) write stories based on images and understand the contents of the story.

The first meeting was held on Tuesday, March 27, 2018, the class was 2-3, with a focus on learning to write stories based on images. The second meeting was held on Wednesday, March 28, 2018 to 5-6 lessons, with the focus of learning to rewrite fairy tales.

\section{Exposure to Meeting 1 Cycle I Actions}

The teacher provides material about the steps to write a story based on the image. After finishing explaining the material, the teacher tells stories 
based on the pictures in the thematic book. Expressions or behavior of class 2 students are very diverse when the teacher tells stories in front of the class, there are students who really listen and listen to stories. But there are also students who do not want to listen but disturb the concentration of their friends.

After the teacher tells a series of images in a thematic book, students are assigned to write a fairy tale based on the images in the thematic book. Before making a fairy tale, students are asked to observe the image first, then make a story based on the image. There are some students who are still confused in arranging some pictures into a fairy tale. They think that each picture has its own story, but actually some of these images are a unified whole, which later when sorted, there will be a continuity, namely the introduction stage, the emergence of conflict and the final stages of the story or fairy tale.

\section{Presentation of Meeting 2 Cycle I Actions}

The teacher presents material as an introduction and students record the material provided by the teacher. In order for students not to get bored in learning activities, the teacher provides a joint variation between fairy tale methods and the method of picture and picture. Furthermore, the teacher provides information about the procedures for playing picture and picture involving all students to play an active role in the learning process. Students are divided into 4 groups.

Group division is done by mentioning 4 types of fruit names starting with students who sit on the front bench at the right hand corner. After a group is formed, the teacher shows several pieces of the picture about a fairy tale and tells the sequence of the pieces of the picture. Then the teacher shares the complete pieces of the picture with each group. Each member of each group holds a piece of picture that will be pasted on the paper on the board. So alternately all students must come forward to paste and sort the images into logical sequences. For students who are not assigned the task of pasting pictures on the board, they are assigned to write stories from the picture sequence and are helped by all of their group friends.

When the teacher attaches blank paper on the board, students discuss a logical sequence of images. To sort and paste pictures on the board, the teacher gives a minimum time limit of 10 seconds for each group. After the picture is pasted, each group is assigned to tell the sequence of the image into a fairy tale. 
But there are some students who do not obey the rules. It has been explained before, that the rules of the game are that each student advances alternately to stick in front or on the board, but in groups 2 and 4 there are several students who progress in groups to attach the image. Finally groups 2 and 4 were disqualified from the game because they did not meet the prescribed rules.

\section{LEARNING PROCESS WITH MENDONGEN IN CYCLE II Cycle II Action Plan}

Based on the results of reflection and research findings in Cycle I, the implementation of learning actions in Cycle II is more emphasized on things that are in nature improvement of learning actions that have been implemented in Cycle I. The action of learning in Cycle II is the same as learning actions in the Cycle I, it's just that there are several different treatments as improvements or improvements to the Cycle I learning action in order to achieve a learning goal.

In the second cycle of action research with Basic Competence (KD) digging information from animal fables (fables) about harmonious living attitudes from oral texts. While the indicators to be achieved are: (a) Digging information from animal fables (fables) about harmonious living attitudes from oral and written texts for the purpose of pleasure, (b) Retelling the fable text describing the harmonious attitude of life read aloud as a form of selfexpression, (c) Determine greetings in fairy tales verbally and in writing, (d) Imitate greetings in fairy tales verbally and in writing.

The first meeting will be held on Tuesday, April 3, 2018 in the 2-3 lessons, with a focus on learning information from fairy tales. The second meeting was held on Wednesday, April 4, 2018 at 5-6.

\section{Exposure to Meeting 1 Cycle II Actions}

When entering into core activities, the teacher provides material about things that must be considered in making an essay. Before the teacher explains the material to be learned, the teacher re-emphasizes the material that has been given before so that students can apply it in making an essay. When the teacher explains the material, some students who usually play alone have begun to pay attention. The teacher asks busy students to explain again what the teacher just said. 
The next activity, the teacher shows a fairy tale through the projector media. The teacher uses audio visual media to present real situations of an event to create a deep impression on students. Students are also very enthusiastic in this activity. All students listen to the fairy tales aired by the teacher carefully. Unlike when teachers tell stories directly without using media or props. After that, the teacher gives assignments to students to retell the tales that have just been watched together. Before entering the closing activity, several students were appointed by the teacher to come to the front of the class and read the results of their work.

\section{Exposure to Meeting 2 Cycle II Actions}

The teacher provides material about the greeting word and explains the material after the student has finished writing it. To get a new atmosphere, the teacher invites students out of class (school yard). Students are asked to sit in a circle around the teacher and then the teacher tells a story in a thematic book. After that, the teacher gives assignments to students to retell the tales that the teacher has just told. The attention of students has begun to focus on learning and student activity begins to increase. This is evidenced by the absence of students talking or playing with their friends when the teacher is telling stories and when the teacher asks questions, they all answer the questions simultaneously from the teacher.

Students who have finished working on the assignment must return to the classroom and collect work results to the teacher. If all students have entered the class, some students are appointed by the teacher to come to the front of the class and read the results of their work.

\section{DISCUSSION}

\section{Results of Improvement and Student Literacy Ability}

Based on the results of observations of the results of learning through fairy tales as described above, the following matters are stated:

\section{a. Process and Literacy Ability in Cycle I}

Based on data from the observation of learning in the first cycle, it can be concluded the following matters:

1) Students show diverse expressions or behavior when the teacher tells stories in front of the class, there are students who really listen and are responsive in listening to fairy tales. But there are also students who do not 
want to listen, but disturb the concentration of their friends who are listening to tales. So students are less enthusiastic in listening to tales because the teacher has not fully become a facilitator;

2) Intelligent students are more dominant in learning activities, because the teacher does not motivate students at lower levels to be able to release their potential;

3) Students have not been actively involved in the learning process using the fairy tale method, this is evidenced by students who still play alone when the learning process takes place;

4) Students when they say / rewrite stories that are heard there are still many who need the help of teachers in the writing procedure, because there are still many students who do not use spelling or punctuation.

The results of the learning material rewrite the story based on the image and rewrite the fairy tale which is shown through the final test results of the first cycle, there are 17 students who score below 75 with the lowest score of 20 and the highest 80. Following the learning results after being given complete action in cycle I. The author can explain in table 2 .

\section{Table 2 Cycle I Test Results}

\begin{tabular}{llll}
\hline No & Value Range & Total & Percentage \\
\hline 1 & $0-74$ & 17 & $44,73 \%$ \\
2 & $75-100$ & 21 & $55,27 \%$ \\
\hline
\end{tabular}

Based on this, the teacher must be able to facilitate all needs in the learning process so students can be interested and happy to take part in learning activities, and can focus on the material conveyed by the teacher. Students must be reminded of material about spelling or punctuation and correct vocabulary usage.

\section{b. Process and Literacy Ability in Cycle II}

Based on the data from observations and learning actions in Cycle II, things can be concluded as follows:

1) Students respond to teacher questions, students are very good, because students always learn first at home before following the lesson the next day;

2) Students begin to be enthusiastic in listening to stories because the teacher has fully become a facilitator; 
3) Students are active in telling / rewriting stories that are still heard there are some students who are incorrect in using spelling or punctuation;

4) Smart students no longer stand out, the teacher has succeeded in motivating students at the lower levels to be more active in expressing their opinions;

5) Students prefer to learn to use pictures or real objects. This is evidenced by all students who are actively involved in working on assignments given by the teacher when they are presented with fairy tales with audio visual media;

6) Observations illustrate that almost all students are active in the learning process using fairytale methods, this is evidenced by the fact that no students joke or play alone when the learning process takes place.

The results of learning fairy-tale rewriting material are shown through the results of the final cycle II test, there are 6 students who score below 75 with the lowest score of 65 and the highest 100 . The following are results of student writing skills after being given actions in Cycle II can be explained in Table 3.

\section{Table 3 Cycle II Test Results}

\begin{tabular}{llll}
\hline No & Value Range & Total & Percentage \\
\hline 1 & $0-74$ & 6 & $15,78 \%$ \\
2 & $75-100$ & 32 & $84,22 \%$ \\
\hline
\end{tabular}

From the results of the analysis in tables 2 and 3, there has been an increase in literacy skills, especially writing skills. This is evidenced by the increase in vocabulary and can begin to use spelling or punctuation correctly and increase the value of students from the initial conditions, Cycle I to Cycle II. Based on the above observations, the researchers decided to stop this study in Cycle II because it was considered successful and the determined KKM had reached 75.00 . 


\section{Graph 1. Comparison of Minimum Completion Criteria in Cycle I and} Cycle II

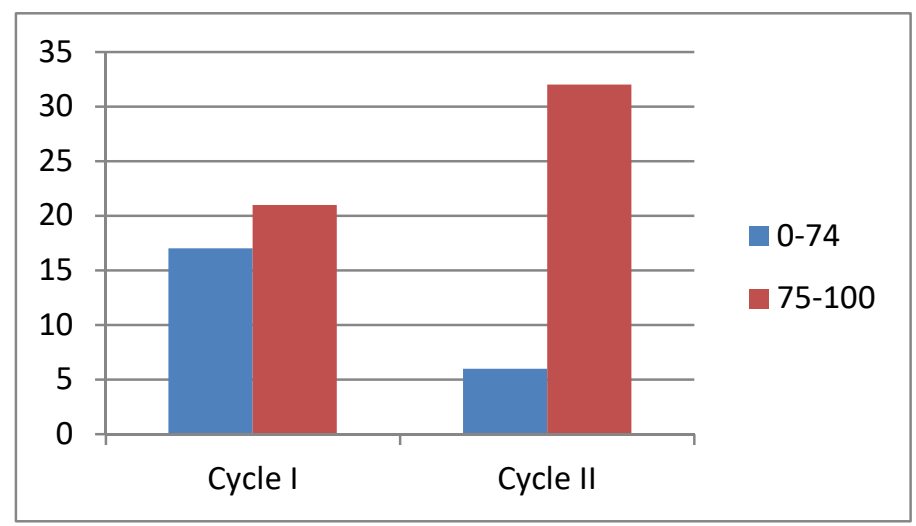

The use of media can increase the ability to understand the contents of a fairy tale. The storyline in this story can enrich children's information and vocabulary (Ardini 2012, 56); through fairy tales can improve speaking skills (Ratnawati 2010, 1). This means that the use of fairy tales methods in elementary school students can improve students' writing skills.

\section{Variations in Storytelling Techniques in Classes}

The teacher applies a variety of storytelling techniques to improve literacy skills. The teacher uses various media and the surrounding environment as material and learning resources. With this technique, student attention can increase.

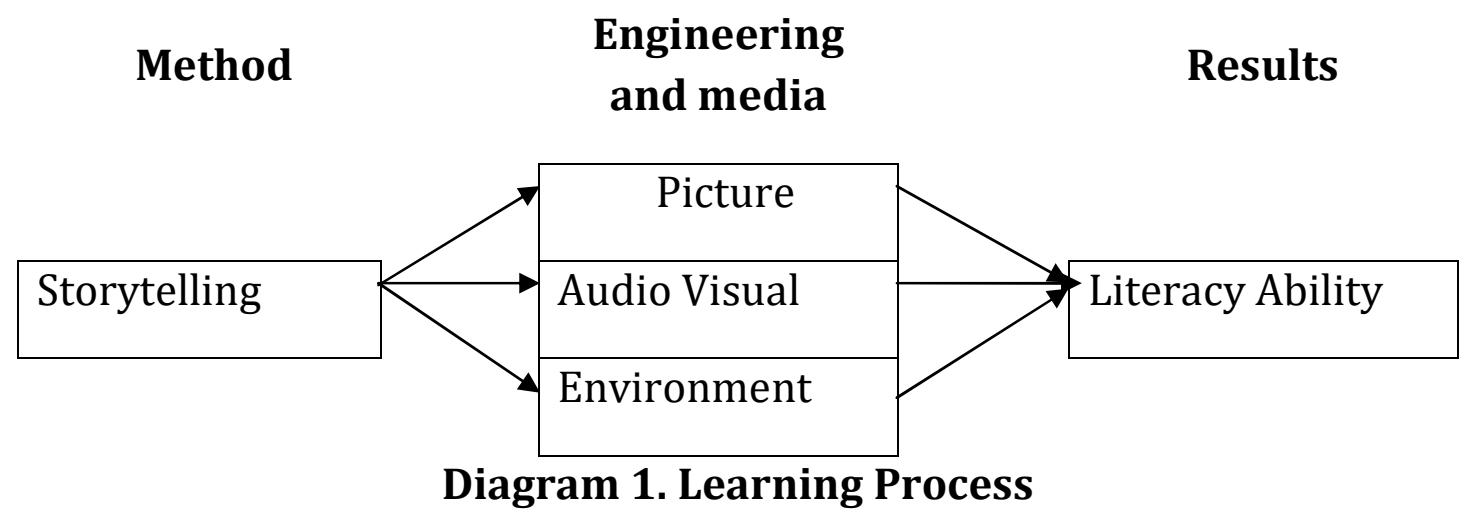

First story by using images in thematic books, and storytelling by arranging pictures on the board. Fairy tales are stories that serve to entertain readers or listeners. Therefore fairy tales must be conveyed to students in a warm atmosphere, on the right occasion, and by integrating media in its delivery. By integrating media, a storyteller can optimize the message 
contained in a story, while simultaneously stimulating the thoughts, feelings, hearing, vision, and interests of students during the learning process. But before delivering a fairy tale, a storyteller must be able to sort out and choose a fairy tale that is suitable for the age of the listener. So the most important thing in this discussion is the teacher's ability to use storytelling media which is supported by the ability to tell the teacher himself. If the teacher is able to use storytelling media and is also able to convey messages interestingly, then the material delivered can be absorbed optimally. Storytelling activities carried out by the teacher in the classroom can be integrated through rewriting the story. In addition to training students' imagination skills, this activity is also able to develop writing skills and can add to the words students have (Patimah 2015, 18). With the picture the learning message will be easily understood by students (Susilana and Riyana 2009, 14). The use of picture media can improve learning processes and results. Series drawing learning media can improve writing skills.

The second story is by using audio visual media. The results of the study confirm that the use of fairy tales will be more effective if using audio visual. The use of audio-visual media, will increase students 'attention to learning and the level of students' understanding of the material is higher. By using this medium the fairy tales delivered are no longer abstract. With images and sounds that can be seen and heard, students can easily capture moral messages in fairy tales (Hidayah and Nurhadija 2018, 73). Furthermore, the results of the study show that after applying fairy tales with audio-visual media, there is an increase in empathy. The initial condition of students' empathy attitude is categorized as low. After applying fairy tales with audio-visual media, the empathy attitude of students increases and grows very well (Limarga 2017, 86; Astuti and Mustadi 2014, 250).

The three were waiting outside the classroom. A variety of mentoring techniques are carried out by the teacher so that the learning process is not boring for students. Learning is a change in reaction activities on the environment (Susanto 2016, 3). Learning concepts like this bring students closer to the environment and learning context, where contextual learning can increase motivation (Ulya, Irawati, and Maulana 2016, 121).

In the second cycle of the second meeting the learning process was conducted outside the classroom. There are a number of things that need to be 
considered in the learning process outside the classroom, including: fulfilling adequate security rules, protecting and enhancing natural characteristics, based on the needs of students, providing opportunities to be active, and pleasant (Maryana and Rachmawati 2013, 38-39).

\section{CONCLUSION}

The conclusions that can be taken in this study are as follows, first, students' literacy literacy abilities have increased. This can be seen an increase in KKM in cycle I to Cycle II. Aspects assessed: writing ideas, organizational content, language style, punctuation, and use of capital letters. The improvement in students' writing skills from the stories delivered by the teacher is inseparable from the use of media and the mengong technique carried out by the teacher. Second, teachers tell stories by using various variations, by using the media and using the outside environment as a place to study. In this way the learning process goes well, there is an improvement in the learning process from cycle I to cycle II, student enthusiasm in learning increases.

\section{REFERENCES}

Abidin, Yunus, Tita Mulyati, and Hana Yunansah. 2017. Strategi Meningkatkan Kemampuan Literasi Matematika, Sains, Membaca Dan Menulis. Jakarta: Bumi Aksara.

Agustini, Dewi. 2015. "Peranan Dongeng Sebagai Media Persuasif Dalam Peningkatan Kemampuan Berbicara Anak Usia Dini Di Paud Alfikr Surakarta." Jurnal Sainstech Politeknik Indonusa Surakarta 2 (4): 26-36.

Ahyani, Latifah Nur. 2010. "Metode Dongeng dalam Meningkatkan Perkembangan Kecerdasan Moral Anak Usia Prasekolah." Jurnal Psikologi Universitas Muria Kudus, 24-32, 1 (1): 9.

Ardini, Pupung Puspa. 2012. "Pengaruh Dongeng Dan Komunikasi Terhadap Perkembangan Moral Anak Usia 7-8 Tahun." Jurnal Pendidikan Anak 1 (1): 44-58.

Asfandiyar, Andi Yudha. 2009. Cara Pintar Mendongeng. Bandung: Mizan.

Astuti, Yanuarita Widi, and Ali Mustadi. 2014. "Pengaruh Penggunaan Media Film Animasi Terhadap Keterampilan Menulis Karangan Narasi Siswa Kelas V SD." Jurnal Prima Edukasia 2 (2): 250-62. https://doi.org/10.21831/jpe.v2i2.2723. 
Azkiya, Nur Rahmatul, and Iswinarti. 2016. "Pengaruh Mendengarkan Dongeng Terhadap Kemampuan Bahasa Pada Anak Prasekolah.” Jurnal Ilmiah Psikologi Terapan 4 (2): https://doi.org/10.22219/jipt.v4i2.3515.

Burgess, Stephen R., Steven A. Hecht, and Christopher J. Lonigan. 2002. "Relations of the Home Literacy Environment (HLE) to the Development of Reading-Related Abilities: A One-Year Longitudinal Study." Reading Research Quarterly 37 (4): 408-26. https://doi.org/10.1598/RRQ.37.4.4.

Çakıroğlu, Orhan. 2012. "Characteristics of Supplemental Reading Classes in American Public High Schools." Elementary Education Online 11 (13): 702-13.

Danandjaja, James. 2002. Foklor Indonesia: Ilmu Gosip, Dongeng, Dan Lain-Lain. Jakarta: Grafiti Pers.

Faizah, Dewi Utama, Susanti Sufyadi, Lanny Anggraini, Waluyo, Sofie Dewayani, Wien Muldian, and Dwi Renya Roosaria. 2016. Panduan Gerakan Literasi Sekolah Di Sekolah Dasar. Jakarta: Direktorat Jenderal Pendidikan Dasar dan Menengah.

Faradina, Nindya. 2017. "Pengaruh Program Gerakan Literasi Sekolah Terhadap Minat Baca Siswa Di SD Islam Terpadu Muhammadiyah AnNajah Jatinom Klaten." Hanata Widya 6 (8): 60-69.

Fuad, A. Jauhar. 2012. Teori Dan Praktik PTK. Tulungagung: STAIN Tulungagung.

Fuad, A. Jauhar, and Manu Winarsih. 2018. "Peningkatan Prestasi Belajar Dengan Metode Bermain Peran Pada Tema Kegiatan Jual Beli." EdHumanistics: Jurnal Ilmu Pendidikan 3 (1). http://ejournal.unhasy.ac.id/index.php/edhumanistics/article/view/251.

Hidayah, Afifah Nur, and Nurhadija. 2018. "Aktivitas Mendongeng Menggunakan Media Audio Visual Dalam Pembelajaran Moral." Jurnal Smart PAUD 1 (1): 73-81.

Kern, Richard. 2000. Literacy and Language Teaching. OUP Oxford.

Khairuddin, Zurina. 2013. "A Study of Students' Reading Interests in a Second Language." International Education Studies 6 (1): 160-70. https://doi.org/10.5539/ies.v6n11p160. 
Limarga, Debora Meiliana. 2017. "Penerapan Metode Bercerita Dengan Media Audio Visual Untuk Meningkatkan Kemampuan Empati Anak Usia Dini." Tunas Siliwangi: Jurnal Program Studi Pendidikan Guru PAUD STKIP Siliwangi Bandung 3 (1): 86-104. https://doi.org/10.22460/ts.v3i1p86104.320.

Maryana, Rita, and Yeni Rachmawati. 2013. Pengelolaan Lingkungan Belajar. Prenada Media.

Mukhtar, Latif, Zukhairina, Rita Zubaidah, and Muhammad Afandi. 2013. Orientasi Pendidikan Anak Usia Dini. Jakarta: Kencana.

Patimah, Patimah. 2015. "Efektifitas Metode Pembelajaran Dongeng Dalam Meningkatkan Kemampuan Literasi Anak Pada Jenjang Usia Sekolah Dasar." Al Ibtida: Jurnal Pendidikan Guru MI 2 (2). https://doi.org/10.24235/al.ibtida.snj.v2i2.123.

Ratnawati, Eka. 2010. "Peningkatan Kemampuan Berbicara Melalui Dongeng Dalam Pembelajaran Bahasa Indonesia Siswa Kelas I Sekolah Dasar Negeri 2 Bendosari Kecamatan Sawit Kabupaten Boyolali Tahun 2010." Other, UNS. https://eprints.uns.ac.id/74/.

Rini, Titis Angga, Titik Harsiati, and Imam Agus Basuki. 2017. "Asesmen Autentik Menulis Untuk Menunjang Penerapan Gerakan Literasi di Sekolah Dasar." In Seminar Nasional Teknologi Pembelajaran dan Pendidikan Dasar 2017, 0:498-506. http://pasca.um.ac.id/conferences/index.php/sntepnpdas/article/view/ 906.

Shofaussamawati, Shofaussamawati. 2016. "Menumbuhkan Minat Baca Dengan Pengenalan Perpustakaan Pada Anak Sejak Dini." Libraria: Jurnal Perpustakaan 2 (1): 46-59. https://doi.org/10.21043/libraria.v2i1.1189.

Squires, Scot. 2014. "The Effects of Reading Interest, Reading Purpose, and Reading Maturity on Reading Comprehension of High School Students." Doctor of Education, Submitted to the Graduate Department and Faculty of the School of Education: Baker University.

Sultan, Ahmad Rofiuddin, Nurhadi, and Endah Tri Prianti. 2017. "The Effect of the Critical Literacy Approach on Pre-Service Language Teachers' Critical Reading Skills." Eurasian Journal of Educational Research (EJER) 6 (71): 159-74. 
Suragangga, I. Made Ngurah. 2017. "Mendidik Lewat Literasi untuk Pendidikan Berkualitas." Jurnal Penjaminan Mutu 3 (2): 154-63. https://doi.org/10.25078/jpm.v3i2.195.

Susanto, Ahmad. 2016. Teori Belajar dan Pembelajaran di Sekolah Dasar. Kencana.

Susilana, Rudi, and Cepi Riyana. 2009. Media Pembelajaran: Hakikat, Pengembangan, Pemanfaatan, dan Penilaian. Bandung: CV.Wacana Prima.

Tarigan, Henry Guntur. 2013. Menulis Sebagai Suatu Keterampilan Bahasa. Bandung: Angkasa.

Ulya, Iik Faiqotul, Riana Irawati, and Maulana Maulana. 2016. "Peningkatan Kemampuan Koneksi Matematis Dan Motivasi Belajar Siswa Menggunakan Pendekatan Kontekstual." Jurnal Pena Ilmiah 1 (1): 121-30. https://doi.org/10.23819/pi.v1i1.2940.

Widayoko, Agus, Supriyono Koes, and Muhardjito Muhardjito. 2018. "Analisis Program Implementasi Gerakan Literasi Sekolah (GLS) Dengan Pendekatan Goal-Based Evaluation." Jurnal Tatsqif 16 (1): 78-92.

Wiedarti, Pangesti, Laksono Kisyani, Pratiwi Retnaningdyah, Sofie Dewayani, Wien Muldian, Susanti Sufyadi, Renya Roosaria, et al. 2016. Desain Induk Gerakan Literasi Sekolah. Direktorat Jenderal Pendidikan Dasar dan Menengah. http://repositori.perpustakaan.kemdikbud.go.id/39/.

Yuwono, Untung. 2007. Gerbang Sastra Indonesia Klasik. Jakarta: Wedatama Widya Sastra. 